\title{
КОНТРАЦЕПТИВНАЯ РЕВОЛЮЦИЯ В РОССИИ
}

\author{
АНАТОЛИЙ ВИШНЕВСКИЙ, БОРИС ДЕНИСОВ, ВИКТОРИЯ САКЕВИЧ
}

\begin{abstract}
В 1960-70-е годы с появлением на рынке гормональной контрацепцฺии и внутриматочной контрацепции нового поколения, в западных странах произошли кардинальные перемены в сфере внутрисемейного регулирования рождаемости настолько значительные, что американские демографы Уэстоф и Райдер назвали их «контрацептивной революцией». K этому времени переход к низкой рождаемости в развитых странах, как, впрочем, и в России, был завершен, и планирование семьи стало массовой практикой, однако появившиеся технологии позволили значительно повысить эффективность контроля рождаемости, что имело важные сочиальные и демографические последствия.
\end{abstract}

Недооченка важности планирования семьи и неразвитость соответствующих служб в СССР и в России привели к тому, что контрацептивная революиия здесь началась с большим опозданием, уже в постсоветские годы с приходом рыночной экономики и информационной открытости. На протяжении десятилетий ключевую роль в регулировании рождаемости играл искусственньй аборт, и только в 90 е годы получили широкое распространение современные методы контрацепции и неблагоприятное соотношение абортов и рождений стало меняться к лучшему. В статье описань структуры применяемых контрацептивных методов в странах европейской культуры и современной России, сделана попытка объяснить различие этих структур.

На материалах наџионального репрезентативного выборочного обследования проанализирована современная практика применения контрацепции в России и сделан вывод о том, что контрацептивная революция в России идет довольно высокими темпами, хотя и не получает существенной поддержки государства.

Ключевые слова: контроль рождаемости, планирование семьи, контращепщия, контрацептивная революиия, аборты, рождаемость.

\section{РЕГУЛИРОВАНИЕ РОЖДАЕМОСТИ В МИРЕ ДО НАЧАЛА КОНТРАЦЕПТИВНОЙ РЕВОЛЮЦИИ}

Известный американский демограф Чарльз Уэстоф многие годы изучал репродуктивное поведение американских семей. В частности, он провел - совместно с Норманом Райдером - два раунда Национального обследования рождаемости: в 1965 и в 1970 гг. В 1975 г., выступая с речью на ежегодном съезде Американской демографической Ассоциации (PAА), президентом которой он был избран, он назвал в качестве наиболее важного результата обследований 1970 г., а в какой-то мере и 1965 г., то, что они позволили зафиксировать необыкновенные изменения в контроле рождаемости - «изменения настолько драматичные, что мы назвали нашу готовящуюся к изданию книгу “Контрацептивная революция”» ${ }^{1}$ [Westoff 1975: 573].

АНАТОЛИЙ ГРИГОРЬЕВИЧ ВИШНЕВСКИЙ (avishnevsky@hse.ru), НАЦИОНАЛЬНЫЙ ИССЛЕДОВАТЕЛЬСКИЙ УНИВЕРСИТЕТ «ВЫСШАЯ ШКОЛА ЭКОНОМИКИ», РОССИЯ.

БОРИС ПЕТРОвИч ДЕНИСов (denisov@demography.ru), МосКОВСКИЙ ГОСУДАРСТВЕННЫЙ УНИВЕРСИТЕТ ИМ. М.В. ЛОМОНОСОВА, РОССИЯ.

ВИКТОРИЯ ИВАНОВНА САКЕВИЧ (vsakevich@hse.ru), НАЦИОНАЛЬНЫЙ ИССЛЕДОВАТЕЛЬСКИЙ УНИВЕРСИТЕТ «ВЫСШАЯ ШКОЛА ЭКОНОМИКИ», РОССИЯ.

СТАТЬЯ ПОДГОТОВЛЕНА ПО РЕЗУЛЬТАТАМ ИССЛЕДОВАТЕЛЬСКОГО ПРОЕКТА «ТЕНДЕНЦИИ ДЕМОГРАФИЧЕСКОГО РАЗВИТИЯ РОССИИ В 2005-2015 ГГ. В КОНТЕКСТЕ ДОЛГОВРЕМЕННЫХ ДЕМОГРАФИЧЕСКИХ ТРЕНДОВ», ВЫПОЛНЕННОГО В РАМКАХ ПРОГРАММЫ ФУНДАМЕНТАЛЬНЫХ ИССЛЕДОВАНИЙ НИУ ВШЭ В 2016 Г.

СТАТЬЯ ПОСТУПИЛА В РЕДАКЦИЮ В НОЯБРЕ 2016 Г.

\footnotetext{
${ }^{1}$ Книга была издана в 1977 г. [Westoff, Ryder 1977].
} 
Действительно ли речь шла о революционных изменениях? К этому времени контрацепция давно уже не была чем-то новым для жителей Западной Европы или США. Речь идет не о редком и, как правило, тайном использовании различных способов предотвращения зачатия, к которому в особых случаях или в особой среде прибегали с незапамятных времен, а о массовой практике, которой в прошлом никогда не существовало. В Европе еще в XVIII веке «поставленная вне общества практика применения противозачаточных средств приравнивалась к пороку, подобному содомии. Даже атеисты XVIII века клеймили это насилие над законами природы» [Сови 1977: 179].

Тем не менее уже с конца XVIII века во Франции отмечалось устойчивое непрерывное снижение рождаемости, которое указывало на то, что практика ее внутрисемейного регулирования становилась массовой. Впоследствии это дало основания французским авторам утверждать, что контрацептивная революция, о которой писали Уэстоф и Райдер в середине 1970-х годов, была второй. Первая же произошла во Франции «в узком кругу семьи, безразличная к потрясениям политической и социальной истории, глухая к площадным дебатам о «депопуляции» Франции и, возможно, немая в исповедальне» [Leridon et al.1987: 14].

Согласно Леридону и соавторам, Франция проложила путь «первой контрацептивной революции», долгое время шла по нему в одиночестве, пока английские и американские неомальтузианцы сражались, казалось бы безуспешно, за право семьи на birth control, подвергаясь преследованиям, навлекая на себя обвинения в безответственности и безнравственности. Но набиравший силу демографический переход делал ограничение рождаемости все более настоятельным требованием, и, в конечном счете, именно французский путь оказался единственно возможным ответом на это требование. Все европейские страны, США и даже Россия стали сворачивать на этот путь и после Первой мировой войны уже уверенно шли именно по нему. С этого времени Франция утратила свое исключительное положение и по уровню рождаемости перестала выделяться на фоне других стран европейской культуры. За очень короткое время рождаемость во всех этих странах упала до небывалого прежде уровня, часто более низкого, чем во Франции (рисунки 1 и 2). Это могло означать только одно: за 3-4 десятилетия еще недавно не признававшаяся здесь практика намеренного ограничения рождаемости в браке стала массовой. Это была поистине революционная перемена.

Итоговая рождаемость реальных поколений женщин, родившихся в 1910 и 1920 г. и, значит, в основном закончивших свою репродуктивную деятельность к 1950-1960 гг. в странах европейской культуры как в самой Европе, так и за океаном (таблица 1), лишь подтверждает сказанное: редкая и в той или иной мере запретная в XIX веке везде, кроме Франции, практика намеренного ограничения рождаемости в браке уже в первой половине XX века стала всеобщей. 


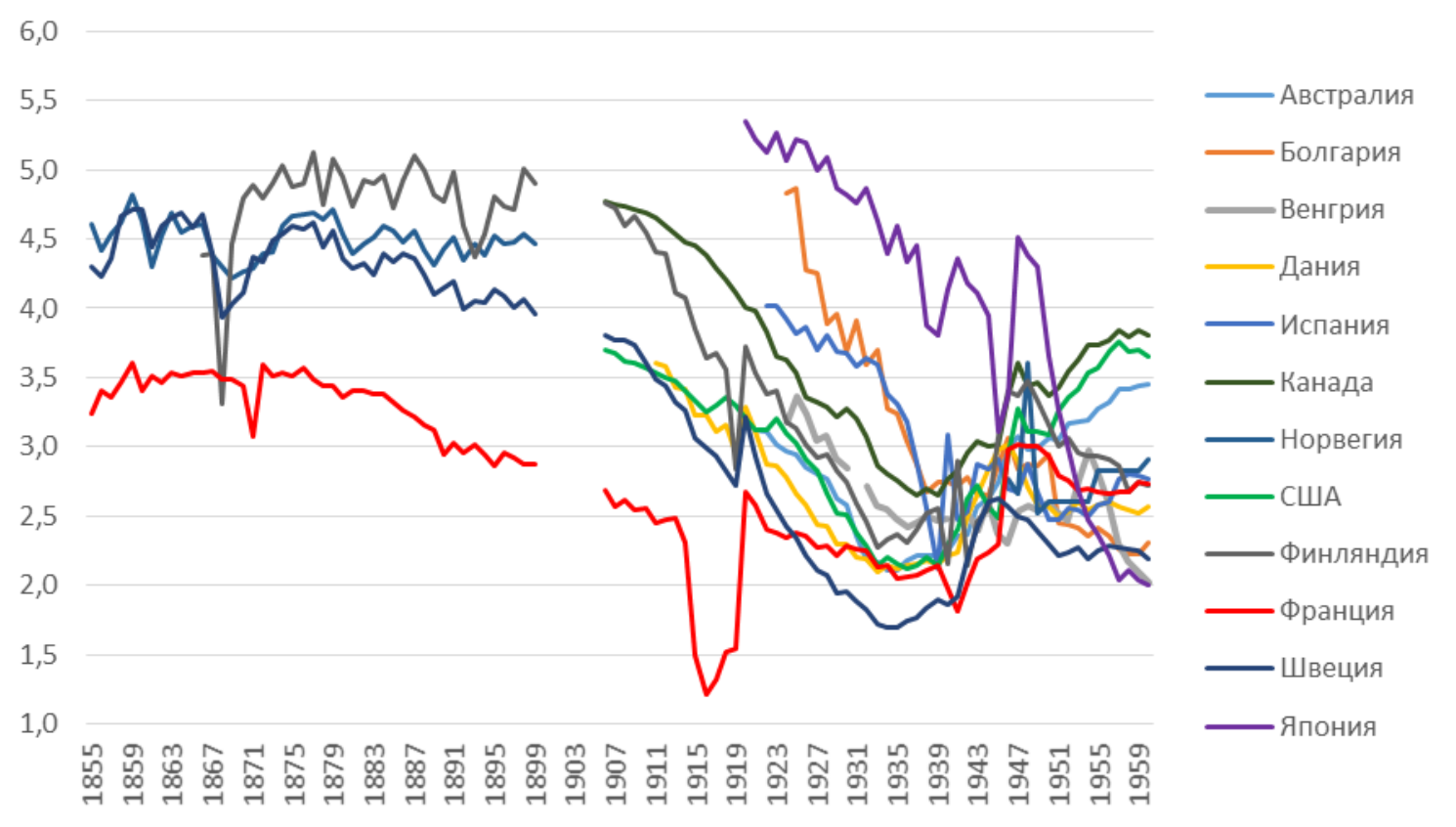

Рисунок 1. Коэффициент суммарной рождаемости в странах европейской культуры и в Японии, 1855-1960; рождений на 1 женщину

Источник: [Chesnais 1986: 517-521].

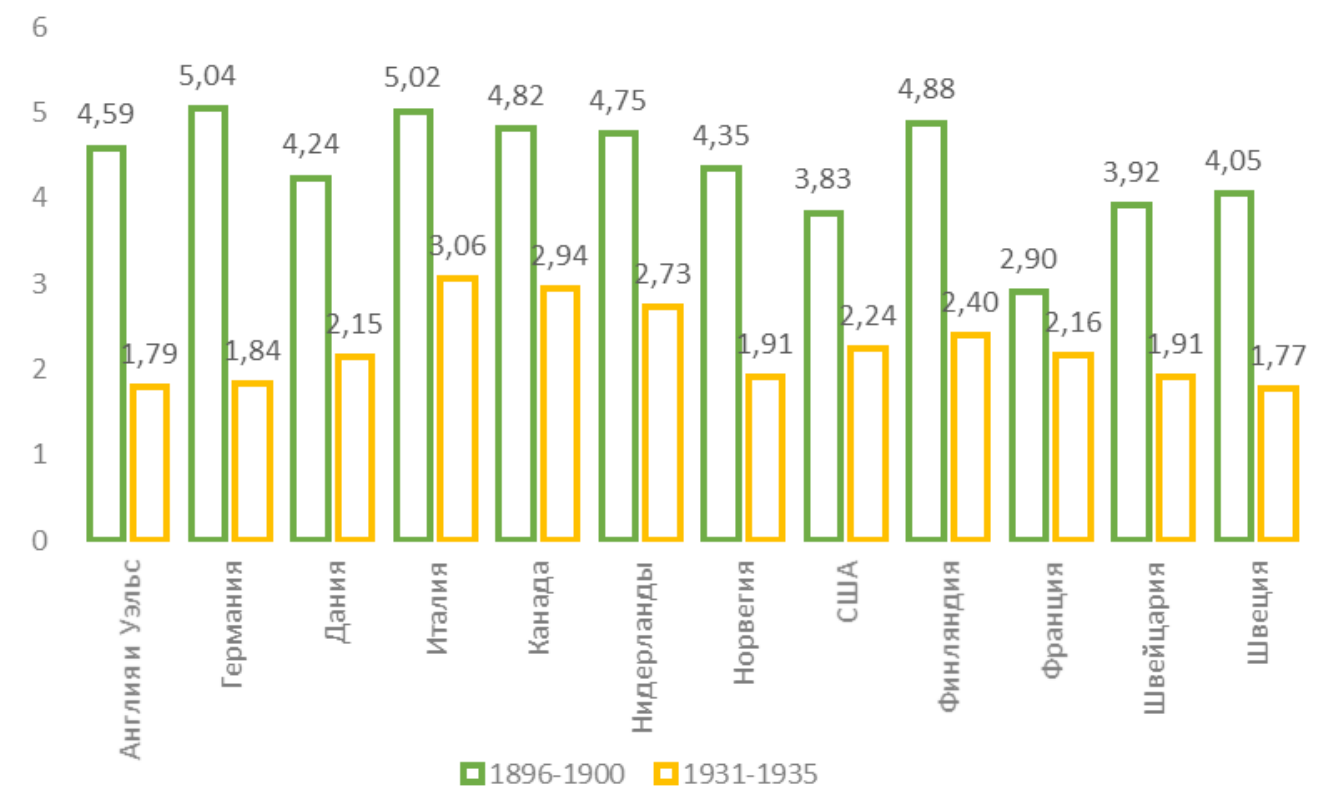

Рисунок 2. Коэффициент суммарной рождаемости в некоторых странах европейской культуры в 1896-1900 (США и Канада - 1901-1905) и в 1931-1935 гг.; рождений на 1 женщину

Источник: [Chesnais 1986: 522-523]. 
Таблица 1. Итоговая рождаемость поколения 1910 и 1920 годов рождения в некоторых странах; рождений на 1 женщину

\begin{tabular}{|c|c|c|c|c|c|}
\hline \multirow[t]{2}{*}{ Страна } & \multicolumn{2}{|c|}{ Число рождений } & \multirow[t]{2}{*}{ Страна } & \multicolumn{2}{|c|}{ Число рождений } \\
\hline & 1910 & 1920 & & 1910 & 1920 \\
\hline Австралия & 2,37 & 2,70 & Нидерланды & $\ldots$ & 3,06 \\
\hline Англия и Уэльс & $\ldots$ & 2,00 & США (белые женщины) & 2,23 & 2,65 \\
\hline Бельгия & 2,05 & 2,13 & Франция & 2,27 & 2,50 \\
\hline Дания & 2,23 & 2,43 & Швейцария & 2,02 & 2,27 \\
\hline Италия & 2,74 & 2,44 & Швеция & 1,89 & 2,14 \\
\hline Канада & 2,76 & 3,18 & Шотландия & $\ldots$ & 2,50 \\
\hline
\end{tabular}

Источник: [Festy 1979: 300-301].

Все это справедливо и в отношении России. На одну россиянку 1891-1895 годов рождения, чья репродуктивная деятельность протекала в основном в первые десятилетия $\mathrm{XX}$ века, несмотря на все потрясения этих десятилетий, приходилось в среднем 5,5 рождения. Для поколений женщин, родившихся в 1921-1925 гг. и проходивших период репродуктивной активности в 1940-е - 1960-е годы, этот показатель уменьшился вдвое - до 2,25 [Демографическая модернизация... 2006: 157]. Внутрисемейное регулирование деторождения налицо.

Вывод: в первой половине XX века в репродуктивном поведении женщин в России, так же как и во всех европейских странах, заокеанских странах европейской культуры, к которым с некоторым опозданием присоединилась и Япония (коэффициент суммарной рождаемости в 1931-1935 гг. - 4,65, в 1961-1965 гг. - 2,0 [Chesnais 1986: 522-523]), произошли огромные, имеющие принципиальное значение перемены. То, что прежде считалось недопустимым, стало общепринятым, подавляющее большинство супружеских пар перешло к сознательному регулированию числа рождений.

Иначе, чем революционными, эти изменения не назовешь, вопрос заключается в том, была ли эта революция только контрацептивной?

До 1960-х годов массовое распространение внутрисемейного регулирования деторождения опиралось на использование давно известных, хотя обычно осуждавшихся методов предупреждения беременности (в основном прерванного полового акта, в меньшей степени - презерватива, женских барьерных методов и спринцевания) или плодоизгнания. Последнее было неизбежно, потому что традиционные способы предотвращения зачатия были недостаточно эффективными и надежными, что, в условиях ширившегося признания права женщины и семьи самим решать вопрос о числе и времени рождения детей, не могло не привести к достаточно широкому распространению искусственного прерывания нежелательных беременностей. Во Франции, например, долгое время «единственным доступным супружеским парам методом был прерванный половой акт, а неудача в его применении могла приводить к аборту (а в первое время, возможно, и к замаскированному детоубийству)» [Leridon et al 1987: 285].

Аборт был повсеместно запрещен и осуждаем, но в XIX веке многие западные страны столкнулись с увеличением числа абортов. Достоверной статистики абортов в период их законодательного запрета, естественно, не существует, имеются лишь некоторые оценки. Согласно таким оценкам, например, во второй половине XIX века в США абортом 
заканчивалась каждая пятая беременность [Potts, Selman 1979: 201]. В Германии в 1890 г. на 100 родов приходилось 8-10 абортов, а в 1924 г. - уже 25 [Генс 1926: 3-4]. Косвенным свидетельством роста распространенности нелегального аборта в Европе может служить увеличение материнской заболеваемости и смертности по этой причине [Паевский 1970: 313-315]. В 1929 г. Мэри Стоупс, одна из наиболее активных поборниц права на контроль рождаемости в Великобритании, открывшая первую в стране клинику планирования семьи, писала: «... очевидно, что падение рождаемости в настоящее время нельзя отнести исключительно на счет «контроля рождаемости», гораздо большую роль играет криминальный аборт» [цит. по: Davey 1988: 333]. В конце XIX - начале XX века распространение аборта начинало тревожить и российское общественное мнение [Демографическая модернизация... 2006: 197-199].

Именно присутствие аборта среди методов регулирования рождаемости и ставит под сомнение интерпретацию изменений в прокреативном поведении людей в первой половине XX века (а они и в самом деле были революционными) как контрацептивной революции.

В то же время, по-видимому, роль аборта в западных странах всегда оставалась второстепенной, основным инструментом регулирования рождаемости действительно стали различные методы предотвращения беременности, а ее прерывание не получило массового распространения. Об этом можно судить по статистике легальных абортов после того, как в 1960-е - 1970-е годы аборт во многих западных странах был разрешен. Аборт вышел из подполья, стал доступен, и статистика свидетельствовала о некотором расширении практики легального прерывания беременности. Но никакого «взрыва» числа абортов не произошло даже на пике роста интенсивности аборта, она была несопоставимо ниже, чем в России в то время. Например, в США после решения Верховного суда, отменившего в 1973 г. запрет аборта, число абортов повысилось до 43-44 на 100 родов в 1979-1984 гг., после чего показатель пошел на убыль. Во Франции, несмотря на декриминализацию аборта в 1975 г., число абортов на 100 родов впоследствии почти никогда не превышало 30. В России же при примерно таком же уровне рождаемости, как в названных странах, на протяжении 1960-х - 1970-х годов число абортов на 100 родов превышало 200, а иногда и $250^{2}$.

Таким образом, применительно к западным странам, пусть и с определенной натяжкой, все же можно говорить о первой контрацептивной революции, хотя скорее речь идет о подготовительной стадии, на которой среди населения этих стран получила широкое распространение практика предупреждения беременности при помощи традиционных, «доиндустриальных» методов [Wrigley 1969: 188-190], что и подвело их к той контрацептивной революции, о которой писали Уэстоф и Райдер.

${ }^{2}$ http://demoscope.ru/weekly/app/app40ab.php 


\section{КОНТРАЦЕПТИВНАЯ РЕВОЛЮЦИЯ НА ЗАПАДЕ}

Именно потому, что практика внутрисемейного регулирования деторождения путем предупреждения беременности становилась на Западе все более массовой, росли и усилия по совершенствованию методов контрацепции с тем, чтобы сделать их более удобными, надежными и безопасными. Первоначальный арсенал таких методов был унаследован от прошлого, когда не было ни технических возможностей для создания эффективных противозачаточных средств, ни большого спроса на них. Теперь же все изменилось, сформировался общественный запрос на более совершенные контрацептивные технологии, а научно-технический прогресс позволил ответить на этот запрос, подобно тому, как это происходило во всех других областях человеческой деятельности. Это и сделало возможной подлинную контрацептивную революцию.

Прорыв был совершен, когда появились гормональные и внутриматочные контрацептивы. Поиски заняли несколько десятилетий. Первый образец внутриматочного средства был создан в 1909 г., идея гормональной контрацепции появилась в начале 1930-х годов. Но и то, и другое достигло необходимых стандартов надежности и безопасности только к началу 1960-х. В 1960 г. были разрешены для повсеместного применения противозачаточные таблетки на основе синтетических гормонов, примерно тогда же началось широкое распространение внутриматочных противозачаточных средств, изготовляемых из инертных пластических материалов. Третьим надежным методом предотвращения зачатия стала хирургическая стерилизация, которая также получила широкое распространение с 1970 г. благодаря введению в хирургическую практику методов мини-лапаротомии и лапароскопии.

Новые технологии стали очень быстро распространяться. На рынке США гормональная или оральная контрацепция (ОК), появилась в 1960 г., а уже к 1970 г. ею пользовались 6 млн женщин или свыше 1/3 замужних женщин, практикующих методы контрацепции [Westoff 1972: 11]. Доля замужних американок, которые применяли один из трех методов (ОК, внутриматочные спирали (ВМС) или хирургическую стерилизацию), среди женщин моложе 45 лет, имеющих риск нежелательного зачатия, составила в 1970 г. 52\%, тогда как в 1965 г. эта доля равнялась 1/3, а в 1960 г. - менеe 10\% [Westoff 1975: 573574]. При этом уровень использования любых методов контрацепции был высок и прежде, этот показатель вырос всего на несколько процентных пунктов, зато сильно изменилась структура методов контрацепции в сторону более эффективных, удобных в применении и, что немаловажно, подконтрольных женщине (в отличие от преобладавших до этого «мужских методов»: прерванного сношения и презерватива).

Схожие тенденции наблюдались в 1960-1970-е годы и в европейских странах. Имеющаяся статистика по Бельгии демонстрирует почти шестикратный рост доли пользователей гормональных таблеток среди всех пользователей контрацепции за 10 лет: с 7\% в 1966 г. до 41\% в 1976 г. [Leridon 1981: 75]. Во Франции в 1968 г. было продано около 6 млн упаковок противозачаточных таблеток, в 1970 - свыше 7 млн, а в 1985 г. число проданных упаковок превысило 47 млн. Число проданных ВМС выросло с примерно 60 тыс. в 1970 г. до 950 тыс. в 1985. В 1968 г. лишь 4\% женщин в возрасте 15-49 лет пользовались гормональными таблетками, в 1985 г. - свыше 27\%. Еще примерно 13-16\% 
женщин пользовались внутриматочными спиралями, тогда как еще в 1971 г. их было менее $1 \%$ [Leridon et al. 1987: 69, 72].

К началу 1980-х годов гормональные таблетки стали самым популярным методом предохранения от беременности во многих западных странах, хотя использовались также и другие пришедшие с контрацептивной революцией методы. Например, в Великобритании набирала популярность стерилизация: если до 1970 г. доля стерилизации в структуре методов была невидима, то в 1976 г. уже 19\%, а в 1986 г. 37\% семей, применяющих методы контрацепции, использовали стерилизацию [Cleland 2009: 167], то же происходило в США и в Канаде. В первой половине 1980-х годов в западных странах число замужних женщин, регулярно прибегающих к современной контрацепции, как правило, превышало 50-60\% (таблица 2).

Таблица 2. Число женщин, использующих различные современные методы контрацепции, на 100 замужних женщин в возрасте до 45 лет

\begin{tabular}{|c|c|c|c|c|c|c|c|c|}
\hline & 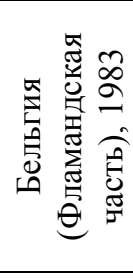 & 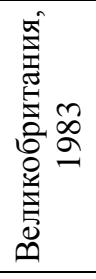 & 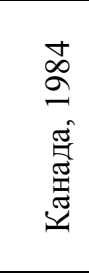 & 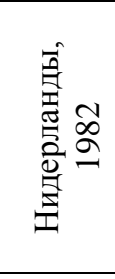 & 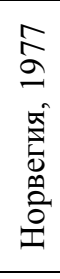 & 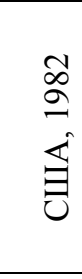 & 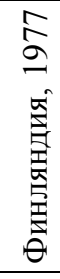 & 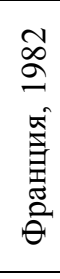 \\
\hline Таблетки & 32 & 25 & 12,7 & 26 & 13 & 13,5 & 11 & 27 \\
\hline BMC & 8 & 5 & 6,7 & 10 & 28 & 4,8 & 29 & 18 \\
\hline Стерилизация & & & & & & & & \\
\hline $\begin{array}{l}\text { женская } \\
\text { мужская }\end{array}$ & 18 & $28 *$ & $\begin{array}{l}28,3 \\
13,2\end{array}$ & $25-30$ & 6 & $\begin{array}{l}27,5 \\
11,4\end{array}$ & 5 & $\begin{array}{l}8 \\
0\end{array}$ \\
\hline Всего & 58 & 58 & 61,0 & $61-66$ & 47 & 52,7 & 45 & 53 \\
\hline
\end{tabular}

Примечание: *- Примерно поровну мужская и женская.

Источник: [Leridon et al. 1987: 286].

К концу 1980-х годов в странах Северной и Западной Европы и Северной Америки современные противозачаточные методы полностью заместили ненадежные традиционные [Frejka, Ross 2001: 233-237], контрацептивная революция в этих странах завершилась. Главным ее итогом стало значительное повышение эффективности внутрисемейного контроля рождаемости, число нежеланных рождений резко сократилось.

Контрацептивная революция на Западе имела важные социальные и демографические последствия. Она сделала возможными многоплановые перемены в поведении людей, получившие впоследствии название «второго демографического перехода». Расширилась свобода формирования индивидуального брачно-семейного календаря, несмотря на снижение возраста сексуального дебюта, появилась возможность откладывать вступление в брак и рождение детей на более поздний срок. Женщины перестали зависеть от мужчин в том смысле, что они теперь сами могли по желанию избегать беременности, так как не зависевшая от них прежде связь между сексом и зачатием была разорвана. Число незапланированных беременностей резко сократилось и стали исчезать прежние вынужденные «браки вдогонку» [Lesthaeghe 2010: 216]. Аборт не исчез полностью, но он сохранился как крайняя мера, к которой прибегают лишь в случаях сбоя или неправильного применения контрацепции. 


\section{СССР: УПУЩЕННЫЕ ВОЗМОЖНОСТИ}

Россия вступила на путь демографического перехода позже многих европейских стран, но на рубеже XIX и XX веков потребность во внутрисемейном регулировании деторождения начала ощущаться и здесь, стала распространяться соответствующая практика. Как и следовало ожидать, поначалу она опиралась на неэффективные и небезопасные методы, в частности, врачи фиксировали значительный рост числа пациенток, перенесших нелегальный аборт [Демографическая модернизация... 2006: 197-199]. Мысль о том, что единственной разумной альтернативой искусственному прерыванию беременности служит ее предотвращение, была ясна многим специалистам в России уже тогда. В качестве примера можно привести выступление доктора Л. Окинчица на 4-м съезде Общества российских акушеров и гинекологов в декабре 1911 г. По мнению докладчика, карательные меры против аборта не приносят результата, а призыв к воздержанию не имеет смысла, поэтому главным путем сокращения практики абортов должны стать «предохранительные от зачатия меры». Л. Окинчиц сформулировал и основные требования к предохранительным средствам: они должны надежно защищать от зачатия, быть совершенно безопасными, легко и удобно применимыми, а также недорогими, чтобы быть доступными бедным слоям населения [Окинчиц 1912: 53-66].

Однако ни до, ни после революции практика предупреждения зачатия не получила у нас полноценного признания и рассматривалась как сугубо медицинская проблема. В официальных документах применение методов контрацепции допускалось главным образом по медицинским показаниям, например, если беременность угрожает жизни и здоровью женщины. В течение десятилетий руководство страны придерживалось догмы, что построение социализма и повышение уровня жизни в советском государстве будут способствовать возвращению массовой многодетности, и, следовательно, в развитии планирования семьи нет необходимости. В постановлении Народного комиссариата здравоохранения и Народного комиссариата юстиции РСФСР, легализовавшем аборт в 1920 г., было указано, что «укрепление социалистического строя» и «широкое осуществление принципов охраны материнства и младенчества» приведут к постепенному исчезновению абортов как следствия «моральных пережитков прошлого и тяжелых экономических условий настоящего» ${ }^{3}$. Как писал в 1920-е годы главный специалист Наркомздрава по планированию семьи А.Б. Генс, СССР не признает неомальтузианского движения, считая, что коренное социальное переустройство улучшит положение трудящихся, что позволит, в том числе, решить и проблему нежелательных беременностей [Генс 1929: 79].

Нельзя сказать, что совсем ничего не делалось в направлении развития службы планирования семьи. Противозачаточные средства были легализованы циркуляром Наркомздрава в 1923 г.; при отделе охраны материнства и младенчества Наркомздрава были созданы Центральная научная комиссия по изучению противозачаточных средств и

\footnotetext{
${ }^{3}$ Постановление Народного комиссариата здравоохранения и Народного комиссариата юстиции РСФСР от 16 ноября 1920 г. «Об искусственном прерывании беременности».
} 
научно-производственная лаборатория. Однако научная база для расширения практики контрацепции находилась на невысоком уровне ${ }^{4}$. Вскоре и эти усилия были свернуты.

В 1936 г., принимая закон о запрете аборта, власти декларировали развитие производства противозачаточных средств. В постановлении Совнаркома от 31 июля 1936 г. ставилась задача расширить производство резиновых изделий (презервативов, пессарий) и других профилактических средств (алюминиевых маточных колпачков, пасты «Преконсоль»). Тогда же было принято решение создать на строящемся заводе в Баковке мощности по производству презервативов. Но эти решения не были выполнены в полном объеме [David, Popov 1999: 237-238], чему не следует удивляться. Ведь ссылки на «условия социализма», «повышение материального благосостояния трудящихся», «максимальное развитие сети родильных домов, детских яслей, детских садов» в законе о запрете аборта 5 имели смысл только в том случае, если противопоставлялись всякому (а не только посредством аборта) ограничению деторождения. В условиях сталинского СССР это практически исключило любую активность, направленную на развитие контрацепции. Немаловажным был также мотив авторитарной власти ограничить свободу личности в принятии решений, в том числе по поводу состава семьи [Авдеев 1989: 59]. «Врачи не обучали женщин применению противозачаточных средств, которых к тому же имелось недостаточно, да и качество их оставляло желать лучшего» [Садвокасова 1969: 125]. В 1939 г. в СССР была запрещена контрацептивная стерилизация ${ }^{6}$.

Отмена в 1955 г. запрета на аборт была лишь признанием повсеместно распространившейся практики прерывания нежелательной беременности. При этом авторы нового закона следовали той же логике, что и авторы законов 1920 и 1936 гг.: «Предотвращение абортов, - говорилось в законе, - может быть обеспечено путем дальнейшего расширения государственных мер поощрения материнства и мер воспитательного и разъяснительного характера» ${ }^{7}$. Не только политики, но и многие специалисты оставались «в сетях концепции помех» [Авдеев 1989: 61]. Так, следуя этой концепции, известный советский социал-гигиенист и медицинский демограф Е.А. Садвокасова, построив сложную систему причин отказа женщин от рождения ребенка, пришла к выводу, что не менее 1/3 абортов являются следствием «безусловно устранимых причин», таких как «недостаток жилой площади», «материальная необеспеченность», «не с кем оставить ребенка», - все они, как предполагалось, будут устранены по мере построения коммунистического общества [Садвокасова 1969: 152-163].

Неудивительно, что в условиях неразвитости службы планирования семьи и дефицита средств контрацепции уровень абортов в России был чрезвычайно высоким

\footnotetext{
${ }^{4}$ Например, обсуждался вопрос о возможности применения в качестве противозачаточных средств «спермотоксинов» или рентгеновских лучей [Генс 1929: 76-90].

${ }^{5}$ Постановление ЦИК и СНК СССР от 27 июня 1936 г. «О запрещении абортов, увеличении материальной помощи роженицам, установлении государственной помощи многосемейным, расширении сети родильных домов, детских яслей и детских садов, усилении уголовного наказания за неплатеж алиментов и о некоторых изменениях в законодательстве о разводах».

${ }^{6}$ Разъяснение Наркомздрава СССР №303 от 7 августа1939 г. «О запрещении операции по перевязке или удалению здоровых маточных труб».

${ }^{7}$ Указ Президиума Верховного Совета СССР от 23 ноября 1955 г. «Об отмене запрещения абортов».
} 
[Демографическая модернизация... 2006: 215-224]. О способах же предупреждения нежелательной беременности в тот период известно немного - соответствующие исследования почти не проводились. По данным проведенного в 1966 г. опроса замужних женщин репродуктивного возраста на нескольких предприятиях Москвы (всего - 1351 человек), несмотря на то, что большинство женщин пытались предохраняться (от 74,5\% в возрасте моложе 25 лет до 92,6\% в возрасте 30-34 года), только 25\% респонденток не имели опыта аборта. Во многих случаях нежелательная беременность наступала на фоне неэффективного применения методов контрацепции, самыми распространенными среди которых были презерватив и прерванное сношение [Белова, Дарский 1972: 126-137]. Другое анкетирование 8 женщин в Москве показало, что основными противозачаточными средствами в начале 1970-х годов были влагалищные спринцевания, прерванное сношение и зачастую неверно трактуемый календарный метод [Полчанова 1973].

Технологические нововведения в области методов регулирования рождаемости, ознаменовавшие контрацептивную революцию на Западе в 1960-1970-е годы, до России дошли не скоро. В частности, упоминавшийся опрос работниц московских предприятий 1966 г. дал основания утверждать, что «... ни пероральные пилюли, ни внутриматочные механические средства, в сущности, совсем не были известны москвичкам» [Белова, Дарский 1972: 135]. Новые противозачаточные средства, распространявшиеся на Западе, в СССР воспринимали с подозрением. Отношение к ним Минздрава СССР было противоречивым, а его политика - вялой и непоследовательной. В 1970 г. в Москве прошел Симпозиум по гормональной контрацепции, в итоговых документах которого был отмечен высокий противозачаточный эффект гормональных контрацептивов. Продолжая закупки зарубежных ОК из Югославии, Венгрии и некоторых других стран, Минздрав СССР дал поручение ведущим НИИ и кафедрам акушерства и гинекологии вести разработки отечественных гормональных средств. Но, как зачастую было в Советском Союзе, благие намерения и даже решения в основном оставались на бумаге. Собственного производства гормональных контрацептивов в России нет до сих пор. В 1974 г. Министерство здравоохранения разослало письмо, в котором побочные эффекты применения оральных контрацептивов были настолько преувеличены, что само дальнейшее их использование оказалось под вопросом9 ${ }^{9}$ Со ссылками на зарубежные источники приводились данные о летальных исходах — не говоря уже о различных нарушениях здоровья - вследствие приема синтетических гормональных препаратов в разных странах.

В условиях конкурентной рыночной экономики западные страны шли по пути постоянного развития и совершенствования противозачаточных средств, уменьшения риска их использования. А Минздрав СССР продолжал акцентировать внимание на анализе осложнений, связанных с приемом гормональных контрацептивов. В 1981 г. было издано новое информационное письмо Минздрава, в котором прямо говорилось: «Трудно

\footnotetext{
${ }^{8}$ Характеристики выборки и процедура опроса не указаны.

${ }^{9}$ Информационное письмо Министерства здравоохранения СССР, Управления по внедрению новых лекарственных средств и медицинской техники, Всесоюзного Центра по изучению побочного действия лекарственных средств от 1974 г. «О побочном действии и осложнениях при применении оральных контрацептивов».
} 
согласиться с мнением..., что положительные медицинские и социальные последствия применения оральных контрацептивов превышают их риск» ${ }^{10}$. Позиция руководителей здравоохранения не могла не вызвать почти враждебного отношения населения к гормональной контрацепции [Кон 2010: 410]. Бороться с высоким уровнем абортов правительство предполагало в основном двумя путями: запугиванием женщин с помощью информации о вреде и опасности прерывания беременности для здоровья и пропагандой материнства и отцовства [Полчанова 1973].

Тем не менее, хоть и медленно, но тональность официальных документов менялась, разворачиваясь в сторону необходимости развития и продвижения противозачаточных средств. Изданные Минздравом СССР в 1983 г. методические рекомендации под названием «Методы предупреждения беременности» начинались со слов: «Внедрение современных контрацептивных средств является основным методом профилактики абортов, снижения гинекологической заболеваемости и акушерской патологии» [Методы предупреждения... 1983]. Ставка была сделана на ВМС как основной метод контрацепции для замужних женщин, и их использование в 1980-е годы действительно быстро росло [Демографическая модернизация... 2006: 227-228]. В документах появились ссылки на «субъективные, психологические» факторы, влияющие на решение прервать беременность, а не только на материальные и жилищные трудности. Однако время было упущено, отставание СССР от развитых стран стало огромным.

Официальная политика в стране сохраняла сильную пронаталистскую направленность, и власти всегда опасались, что продвижение планирования семьи приведет к дальнейшему снижению рождаемости.

Настороженное отношение к гормональной контрацепции разделяли и врачи, которые должны были бы, наоборот, всячески продвигать этот современный метод. «Сдерживающим фактором к распространению [гормональной контрацепции] ...является негативное отношение акушеров-гинекологов к применению гормональных таблеток», констатировал Минздрав России в 1992 г. $^{11}$

В целом, несмотря на некоторые позитивные перемены в годы перестройки ${ }^{\mathbf{1 2}}$, советский период был временем застоя во всем, что касалось развития необходимых подавляющему большинству женщин и супружеских пар современных методов планирования семьи. К концу существования Советского Союза контроль рождаемости в стране характеризовался широкой распространенностью аборта, неразвитостью услуг по

\footnotetext{
${ }^{10}$ Информационное письмо Министерства здравоохранения СССР, Управления по внедрению новых лекарственных средств и медицинской техники, Всесоюзного Центра по изучению побочного действия лекарственных средств от 1981 г. «О побочных реакциях и осложнениях, вызываемых оральными контрацептивами».

${ }^{11}$ Письмо Министерства здравоохранения Российской Федерации руководителям органов управления здравоохранением и фармацией административных территорий Российской Федерации №06-15/7-15 от 30 июля 1992 г. «О состоянии с абортами в России и организации службы планирования семьи».

${ }^{12}$ Например, в 1989 г. постановлением ЦК КПСС (!) была создана ассоциация «Семья и здоровье», в задачи которой входило предоставление информации о методах планирования семьи и самих противозачаточных средств.
} 
планированию семьи, дефицитом средств контрацепции и низким уровнем сексуальной культуры населения. Нельзя не отметить и отсутствие сколько-нибудь подробной статистики абортов, ведение которой в условиях легализации аборта не представляет никаких трудностей.

\section{НАЧАЛО КОНТРАЦЕПТИВНОЙ РЕВОЛЮЦИИ В ПОСТСОВЕТСКОЙ РОССИИ}

В постсоветский период положение стало меняться. Появление рынка, в том числе рынка современных средств контрацепции, и информационная открытость в течение нескольких лет существенно изменили ситуацию.

Важную роль в вытеснении практики аборта контрацепцией сыграла федеральная целевая программа «Планирование семьи», принятая в начале 1990-х годов и в 1994 г. получившая статус «президентской». В Указе Президента говорилось, что главным основанием для разработки программы была «высокая распространенность абортов при снижении рождаемости... Аборт остается главным методом регулирования рождаемости, ежегодно производится около 4 млн абортов. В 1991 году, по данным Госкомстата России, показатель частоты абортов на 1000 женщин детородного возраста составил 100,3. В структуре материнской смертности аборты составляют одну треть». Была обозначена цель «снизить число абортов на 25 - 30 процентов от исходного уровня» ${ }^{13}$.

Впервые в России начала создаваться государственная служба планирования семьи, оснащенная современным оборудованием и обеспеченная средствами контрацепции «в нужном объеме и ассортименте». В рамках программы велась работа по повышению информированности населения в вопросах предупреждения нежелательной беременности. Предусматривалось введение системы полового воспитания подростков. Около $40 \%$ средств программы «Планирование семьи» ежегодно выделялось на закупки гормональных контрацептивов, благодаря чему многие учреждения здравоохранения имели возможность бесплатно раздавать их социально незащищенным группам населения, например молодежи, малообеспеченным женщинам [Шарапова, Баклаенко 2003: 4]. Были организованы курсы подготовки и повышения квалификации специалистов по вопросам профилактики абортов и безопасного материнства. Аналогичные программы были приняты в регионах.

Программа в значительной степени была инициирована Российской ассоциацией «Планирование семьи», существовавшей с 1991 г. и позднее под воздействием политической конъюнктуры переименованной в Российскую ассоциацию «Народонаселение и развитие». Одна из уставных целей Ассоциации - «содействие внедрению современных методов контрацепции для профилактики непланируемых беременностей и абортов, для снижения уровня материнской смертности, для рождения желанных и здоровых детей».

Вся эта деятельность полностью соответствовала позиции международных организаций, сформулированной, в частности, в докладе Каирской международной

\footnotetext{
13 Указ Президента РФ №1696 от 18 августа 1994 г. «О президентской программе "Дети России"». 
конференции по народонаселению и развитию 1994 г.: «Правительствам следует предпринять соответствующие шаги, чтобы помочь женщинам избегать аборта, который никоим образом не должен пропагандироваться в качестве метода планирования семьи, и во всех случаях обеспечить гуманное обращение с прибегшими к аборту женщинами и их консультирование» [ООН 1994: 7 пункт 7.24].

Программа «Планирование семьи» получала финансирование (может быть, не очень щедрое) из государственного бюджета. Существенную финансовую и техническую помощь также оказывали международные организации, правительственные и частные зарубежные фонды, в частности Агентство США по международному развитию (USAID) и Фонд ООН в области народонаселения (UNFPA).

Программа оказалась очень успешной, наиболее красноречиво об этом говорит быстрое снижение числа абортов, которого не удавалось добиться несколько десятилетий. Число абортов на 100 родов, иными словами, доля беременностей, заканчивающихся абортом, начало снижаться именно с 1994 г., когда была принята президентская программа планирования семьи, и падало, несмотря на снижение рождаемости: аборт явно терял свою роль метода регулирования деторождения, уступая ее контрацепции. С тех пор число рождений неуклонно сближается с числом зачатий, что свидетельствует о все более эффективном планировании семьи (рисунок 3).

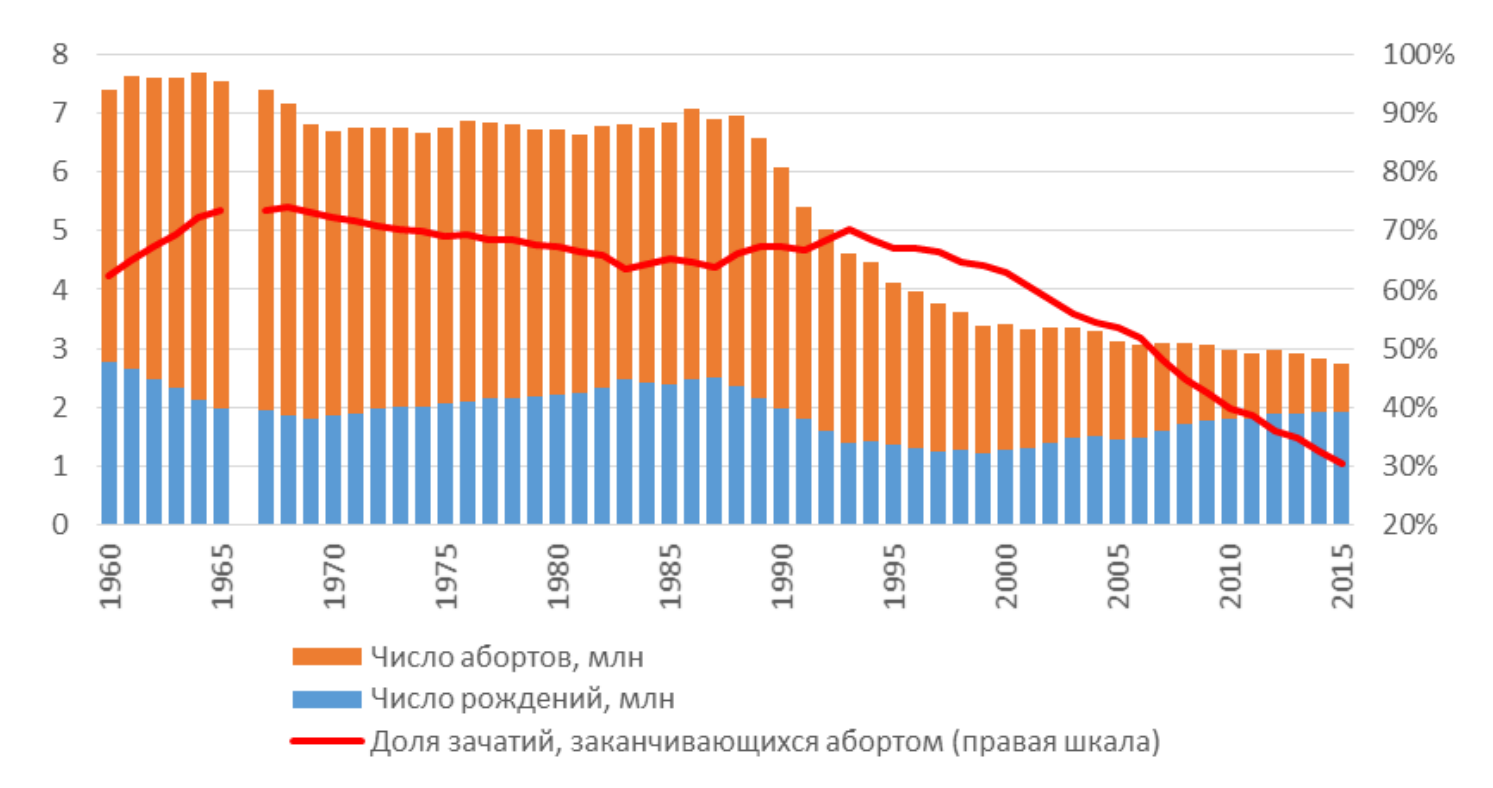

Рисунок 3. Число рождений, число абортов и доля зачатий, заканчивающихся абортом, 1960-2015

Примечание: За число зачатий принята сумма рождений и абортов.

Источник: Расчеты авторов на основе данных Pосстата.

В 2015 г. число абортов на 100 родов было более чем в 5 раз ниже, чем в 1993 г., после которого началось снижение. Сейчас уже можно с уверенностью говорить, что, хотя российские показатели интенсивности абортов все еще выше соответствующих показателей стран, прошедших через контрацептивную революцию, разрыв между ними с 
каждым годом сокращается (рисунок 4). Значит ли это, что эта революция совершается также и в России? И если да, то как далеко она продвинулась?

Чтобы ответить на эти вопросы, надо проанализировать современную практику применения контрацепции в России.

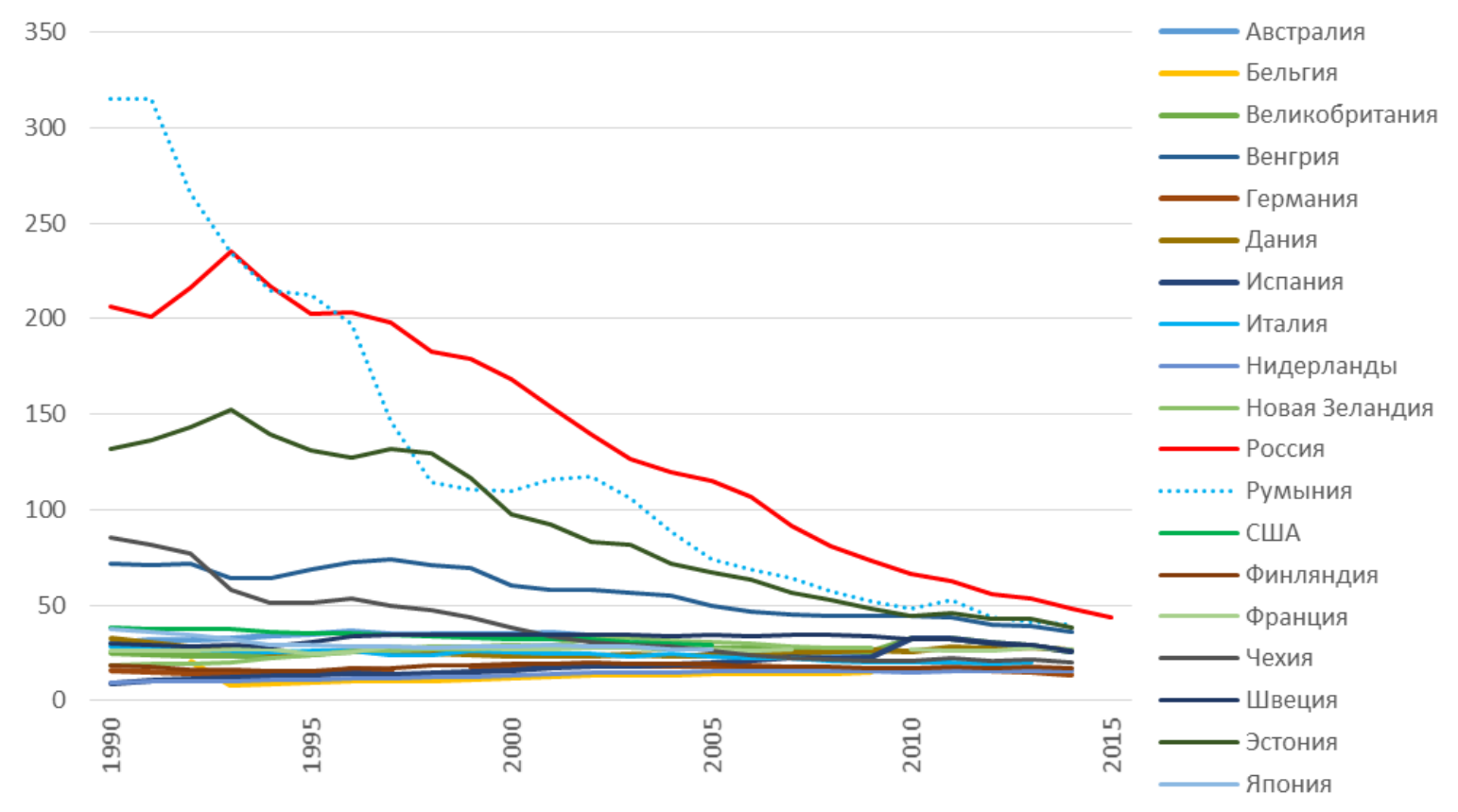

Рисунок 4. Число абортов на 100 родов в некоторых странах

Источник: [ВОЗ Европейское бюро].

\section{СОВРЕМЕННАЯ ПРАКТИКА ПРИМЕНЕНИЯ КОНТРАЦЕПЦИИ В РОССИИ}

Низкая интенсивность абортов при низкой рождаемости служит несомненным признаком массовой практики внутрисемейного планирования деторождения. Однако мы видели, что в западных странах эта практика была достаточно широко распространена и до начала «второй» контрацептивной революции, которая коренным образом изменила структуру используемых методов предупреждения зачатия. Что происходит с этой структурой в России? В какой мере современная контрацептивная практика россиян основана на использовании контрацептивов последнего поколения, а в какой применяемые методы еще остаются традиционными, т.е. недостаточно удобными, надежными и эффективными?

Главным источником сведений о контрацептивном поведении обычно служат выборочные опросы населения. К сожалению, в России вплоть до 2011 г. специальные обследования репродуктивного здоровья населения, репрезентативные на национальном уровне, не проводились. Некоторые сведения об использовании контрацепции содержались в программе двух волн обследования «Родители и дети, мужчины и женщины в семье и обществе (РиДМиЖ)» 2004 и 2007 г. [Сакевич 2009; 2010]. Ряд вопросов, касающихся планирования семьи, входит в программу «Российского мониторинга экономического 
положения и здоровья населения НИУ ВШЭ (RLMS-HSE)» ${ }^{14}$. Ценная информация об этой малоизвестной стороне частной жизни россиян была получена в результате нескольких региональных обследований, например в Екатеринбурге, Перми и Ивановской области [Троицкая, Андерссон 2011], но насколько они репрезентативны для страны в целом, неясно.

В 2011 г. в России впервые было проведено специальное «Выборочное обследование репродуктивного здоровья российских женщин (ВОР3)» ${ }^{15}$, программа которого среди прочего содержала сбор подробной информации о знаниях, отношении и опыте использования контрацепции в России. В данной статье мы используем результаты этого уникального обследования.

Как ВОРЗ, так и все другие недавние выборочные обследования, которые затрагивали вопросы планирования семьи, свидетельствуют о том, что сегодня распространенность контрацепции в России высока. Подавляющее большинство пар для регулирования рождаемости прибегает к методам контрацепции, хотя и не всегда успешно.

Согласно ВОР3, 72,3\% женщин в возрасте от 15 до 44 лет, состоящих в браке или партнерстве, применяли методы контрацепции в течение 30 дней перед опросом (таблица 3). Россия здесь мало отличается от других стран с постпереходным типом рождаемости. Очень близкие к российскому показатели распространенности контрацепции характерны для таких стран, как Австралия, Бельгия, Германия, Австрия, Испания, Румыния и многие другие. Правда, в ряде стран уровень использования контрацепции еще выше: в Норвегии $88,4 \%$, Чехии 86,3\%, Канаде и Китае $85 \%$ состоящих в партнерстве женщин применяют методы контрацепции [UN 2016].

$27,7 \%$ состоящих в браке респонденток репродуктивного возраста ответили, что не предохраняются от беременности в настоящее время, при этом почти 85\% из них в качестве причины неиспользования методов контрацепции назвали текущую беременность, послеродовой период, желание забеременеть или невозможность забеременеть, отсутствие половой жизни; всем этим категориям женщин не нужна контрацепция. Небольшая часть женщин среди не применяющих контрацепцию сказали, что не думали о контрацепции $(2,6 \%)$ или не хотели ее использовать (3,3\%), боятся побочных эффектов $(2,2 \%)$, уступают партнеру, который возражает против применения контрацепции $(1,9 \%)$. Лишь единицы не используют противозачаточные методы из-за того, что не знают, где их можно приобрести, из-за высокой цены или в силу своих религиозных убеждений.

Современные методы предпочитают 57,5\% женщин в возрасте 15-44 года, состоящих в браке или партнерстве, или около $80 \%$ пользователей контрацепции, и в этом заключается главное отличие сегодняшней ситуации от того, что было во времена СССР. Самый популярный противозачаточный метод среди российских семей - презерватив, по

\footnotetext{
${ }^{14} \mathrm{https}: / /$ www.hse.ru/rlms

15 Обследование проведено Росстатом совместно с Минздравом РФ при содействии Фонда ООН в области народонаселения, Агентства США по международному развитию и отдела репродуктивного здоровья Центров по контролю и профилактике заболеваемости (США); полевые работы осуществлял ИИЦ «Статистика России». Было получено 10010 ответов женщин в возрасте 15-44 года.
} 
данным ВОРЗ, его применяют почти 27\% пар или 37\% пользователей контрацепции. Презерватив считается методом средней эффективности, поскольку трудно достичь идеального его использования на практике ${ }^{16}$. Второй по распространенности метод внутриматочная контрацепция (14,2\% пар), затем идет гормональная контрацепция $(13,2 \%)$. Вопрос о том, почему россияне отдают предпочтение презервативу, требует дополнительного исследования. Одной из версий может быть нежелание лишний раз общаться с государственной медициной, недоверие к ней, стремление избежать «медицинского надзора» в такой приватной сфере, как сексуальная жизнь [Тёмкина 2011: 221-226; 2013: 10], а презерватив можно свободно купить в супермаркете. Возможно, какую-то роль играет страх перед угрозой заражения ВИЧ/СПИДом и другими инфекционными заболеваниями, передаваемыми половым путем [Тёмкина 2011: 213-215], уровень заболеваемости которыми в России высок.

Таблица 3. Доля женщин 15-44 лет, применяющих контрацепцию, по данным Выборочного обследования репродуктивного здоровья российских женщин (ВОР3), 2011, \%

\begin{tabular}{l|c|c}
\hline & $\begin{array}{c}\text { Женщины, } \\
\text { состоящие в } \\
\text { браке/партнерств }\end{array}$ & $\begin{array}{c}\text { Сексуально активные } \\
\text { женщины, никогда не } \\
\text { состоявшие в браке }\end{array}$ \\
\hline Какой-либо метод контрацепции & 72,3 & 89,9 \\
Современный метод & 57,5 & 79,2 \\
в том числе: & 26,6 & 65,1 \\
$\quad$ презерватив & 14,2 & 0,4 \\
ВМС & 13,2 & 11,1 \\
$\quad$ гормональные таблетки (оральная контрацепция) & 1,3 & 1,7 \\
спермициды & 1,5 & - \\
стерилизация женщин & 0,7 & 1,0 \\
другой & 14,8 & 10,7 \\
Традиционный метод & & 1,1 \\
в том числе: & 4,2 & 9,5 \\
$\quad$ календарный & 10,1 & - \\
прерванный половой акт & 0,1 & 10,1 \\
другой & 27,7 & 100 \\
Не применяют контрацепцию & 100 & 447 \\
Всего & 6091 & \\
Число респондентов & & \\
\hline
\end{tabular}

Примечание: Респонденты, не ответившие на вопрос, исключены.

Источник: Расчеты авторов на основе базы данных обследования.

Предпочтения, отдаваемые тому или иному методу, различаются в зависимости от возраста (таблица 4). В возрасте до 25 лет женщины, состоящие в браке/партнерстве, в 1,4 раза чаще используют гормональную контрацепцию, чем в возрасте 30-34 года, тогда как

\footnotetext{
${ }^{16}$ При регулярном использовании контрацепции в течение 12 месяцев риск неудачи при использовании традиционных методов оценивается в 14-26 непредотвращенных беременностей в расчете на 100 человеколет (разумеется, расчет относится только к женщинам). При использовании современных методов риск неудачи снижается до менее чем одной непредотвращенной беременности на 100 человеко-лет. Соответствующий показатель для мужского презерватива, который обычно относят к современным методам, оценивается в 14 непредотвращенных беременностей в расчете на 100 человеко-лет [Frejka 2008: 74].
} 
применение ВMC, наоборот, намного более распространено в возрастных группах старше 30 лет. Но презерватив занимает первое место по популярности во всех возрастных группах от 15 до 45 лет.

Таблица 4. Структура методов контрацепции в зависимости от возраста применяющих контрацепцию. Женщины, состоящие в зарегистрированном или незарегистрированном браке, 2011, \%; по данным Выборочного обследования репродуктивного здоровья российских женщин (ВОРЗ)

\begin{tabular}{l|c|c|c|c|c|c}
\hline & \multicolumn{7}{c}{ Возраст женщины, лет } \\
\cline { 2 - 7 } & $15-44$ & моложе 25 & $25-29$ & $30-34$ & $35-39$ & $40-44$ \\
\hline Используют контрацепцию & 100 & 100 & 100 & 100 & 100 & 100 \\
Современный метод & 79,5 & 79,8 & 79,0 & 80,8 & 79,4 & 78,5 \\
в том числе: & 18,2 & 22,2 & 20,6 & 21,5 & 15,5 & 11,8 \\
$\quad$ ОК & 19,6 & 6,8 & 13,7 & 22,2 & 25,1 & 26,5 \\
$\quad$ ВМС & 36,8 & 49,1 & 42,6 & 33,0 & 29,9 & 33,6 \\
$\quad$ презерватив & 20,5 & 20,2 & 21,0 & 19,2 & 20,6 & 21,5 \\
Традиционный метод &
\end{tabular}

Источник: Расчеты авторов на основе базы данных ВОРЗ.

В ходе ВОРЗ выяснилось, что 14,8\% состоящих в браке или партнерстве женщин полагаются только на традиционные методы, обладающие невысокой надежностью. Это, конечно, значительно меньше, чем в советский период, но и не так мало. В Западной Европе традиционные методы сегодня применяют не больше 5\% пар. Основными мотивами отказа от современных методов контрацепции российские женщины называли: боязнь побочных эффектов (77\% пользователей традиционных методов), выбор мужа/партнера (77\%) и низкую доступность современных средств (65\%). На такие причины, как религиозные убеждения или высокая цена контрацептивов, респондентки ссылались крайне редко.

Никогда не состоявшие в браке, но сексуально активные женщины применяют методы контрацепции чаще, чем замужние (таблица 3), что вполне ожидаемо. Среди этих женщин 65,1\% указали на применение презерватива.

Чтобы оценить изменения в контрацептивном поведении россиян за несколько последних десятилетий, сравним данные ВОРЗ с результатами опроса женщин в трех городах России (Москве, Саратове и Уфе), проведенного в 1983-1985 гг. Выборка 1983-1985 гг. включала замужних женщин моложе 35 лет, проживающих совместно с партнером и имеющих одного или двух детей. Соответственно среди респондентов ВОРЗ нами были выбраны женщины того же возраста, брачного состояния и числа рожденных детей, проживающие в городах России.

Таблицы 5 и 6 убедительно показывают, что информированность о методах контрацепции и отношение к ним претерпели значительные изменения за последние 25 - 30 лет.

В середине 1980-х годов взгляды населения на различные способы контроля рождаемости формировались в условиях весьма ограниченной информации, а то и дезинформации относительно средств контрацепции и были крайне неполными, а часто и неверными. О существовании гормональной контрацепции в 1983-1985 гг. не знали 25-31\% молодых городских женщин, тогда как сейчас об этом методе знают практически все. 
Согласно опросу 2011 г. из практики исчез такой метод, как спринцевание, о его применении заявили всего 6 женщин из почти 2 тысяч. По сравнению с серединой 1980-х годов, уменьшилась доля знающих о спермицидах, зато появилась информация о стерилизации и контрацептивных инъекциях, которые в советское время не применялись.

То, что женщины слышали о том или ином методе в 1980-е годы, совершенно не означало, что они хорошо себе представляли, каково его действие. На вопросы о свойствах методов контрацепции многие жительницы Москвы, Саратова и Уфы отвечали «не знаю», а остальные относились к большинству методов с недоверием (таблица 5). Лишь 7-18\% опрошенных женщин считали оральную контрацепцию надежным и 4-6\% - безвредным для здоровья методом предохранения от беременности. Самым эффективным (хотя и небезопасным) жительницы Москвы и Саратова в 1980-х годов назвали метод прерванного полового сношения. Очевидно, что в малых городах и селах ситуация была еще хуже.

Сегодняшние горожанки гораздо более грамотны в этом вопросе, хотя и сейчас всего 18,5\% молодых городских женщин не видят в гормональных контрацептивах угрозы для здоровья, а 70\% считают, что их прием ведет к прибавке массы тела. Многолетняя дискредитация гормональной контрацепции принесла свои плоды. До сих пор можно услышать от женщин: «они [гормональные таблетки] вредны для печени, прежде всего, как любые лекарства, которые принимаешь» или «если говорить о таблетках, мне кажется, от них толстеют» [Тёмкина 2011: 217].

За время, прошедшее между двумя опросами, отношение к презервативу значительно улучшилось (сегодняшние презервативы действительно трудно сравнить по качеству с советскими), однако ухудшилось мнение о безопасности ВМС. «Очень эффективным» противозачаточным методом в 2011 г. чаще всего респондентки называли женскую стерилизацию (53\%) (а не прерванное сношение, как в середине 1980-х), затем ВМС (26\%) и ОК (20\%), а вот гормональные инъекции, вероятно, еще мало знакомы россиянкам - очень эффективными их посчитали лишь $3 \%$.

Таблица 5. Знания о методах контрацепции. Женщины моложе 35 лет, проживающие совместно с партнером и имеющие одного или двух детей, \% опрошенных

\begin{tabular}{l|c|c|c|c}
\hline \multirow{2}{*}{ Метод контрацепции } & \multicolumn{3}{|c|}{$1983-1985$} & 2011 \\
\cline { 2 - 5 } & Москва & Саратов & Уфа & городское население России \\
\hline ВМС & 95,6 & 94,8 & 96,2 & 98,0 \\
Оральная контрацепция & 75,0 & 69,4 & 69,4 & 98,8 \\
Презерватив & 97,5 & 98,1 & 96,8 & 99,8 \\
Химические средства (спермициды) & 76,0 & 74,6 & 74,3 & 54,0 \\
Женская стерилизация & - & - & - & 77,0 \\
Мужская стерилизация & - & - & - & 59,1 \\
Инъекции & - & - & - & 26,2 \\
Прерванный половой акт & 93,6 & 91,6 & 86,7 & 92,5 \\
Календарный метод & 95,1 & 91,7 & 91,6 & 80,4 \\
Спринцевание & 86,8 & 89,5 & 89,5 & н/д \\
\hline
\end{tabular}

Примечание: Число респонденток в 1983-1985 г2. - 1000, число респонденток в 2011 г. - 1973. В анкете ВОР3-2011 вопрос был сформулирован следующим образом: «Bы когда-либо сльищали о ...?».

Источники: 1983-1985 г2. - [Бабин 1986]; 2011 г. -расчеты авторов на основе базы данных ВОРЗ. 
Таблица 6. Мнения о методах контрацепции. Женщины моложе 35 лет, проживающие совместно с партнером и имеющие одного или двух детей, \% опрошенных

\begin{tabular}{l|rr|r|r}
\hline & \multicolumn{3}{|c|}{$1983-1985$} & 2011 \\
\cline { 2 - 5 } & Москва & Саратов & Уфа & городское население России \\
\hline Считают метод эффективным (надежным)* & & & & \\
ВМС & 29,9 & 26,6 & 34,3 & 88,6 \\
оральная контрацепция & 18,1 & 7,0 & 8,9 & 91,0 \\
презерватив & 36,8 & 34,7 & 29,5 & 93,5 \\
химические средства (спермициды) & 3,4 & 4,1 & 6,7 & H/д \\
женская стерилизация & - & - & - & 68,5 \\
инъекции & - & - & - & 17,8 \\
прерванный половой акт & 41,7 & 39,7 & 29,3 & 65,9 \\
календарный метод & 23,0 & 30,7 & 31,2 & 44,7 \\
спринцевание & 15,7 & 14,3 & 15,6 & H/д \\
Считают метод безопасным для здоровья (безвредным)** & & & \\
ВМС & 20,6 & 25,5 & 28,5 & 16,6 \\
оральная контрацепция & 6,4 & 5,1 & 3,7 & 18,5 \\
презерватив & 48,5 & 45,7 & 34,6 & 88,9 \\
химические средства (спермициды) & 11,8 & 8,5 & 14,8 & /д \\
женская стерилизация & - & - & - & 4,2 \\
инъекции & - & - & - & 1,8 \\
прерванный половой акт & 10,3 & 7,2 & 5,6 & н/д \\
календарный метод & 75,0 & 77,1 & 70,1 & н/д \\
спринцвание & 36,3 & 37,7 & 43,2 & /д \\
\hline
\end{tabular}

Примечания: * - Для 2011 г. объединены ответы: «очень эффективен», «эффективен» и «в какой-то степени эффективен». ** - Для 2011 г. взят ответ: «низкая степень угрозы для здоровья».

Источники: 1983-1985 г2. - [Бабин 1986]; 2011 г. - расчеты авторов на основе базы данных ВОРЗ.

Уровень использования контрацепции за рассматриваемый период мало изменился, однако произошли кардинальные перемены в структуре применяемых методов контрацепции (таблица 7). Мы видим очевидное падение популярности традиционных методов (прерванного полового акта, спринцевания и календарного метода), суммарная доля которых среди всех применяющих контрацепцию снизилась с 60-65\% в 1980-е годы до $21 \%$ в 2011 г.

Особенно бросается в глаза рост доли оральной контрацепции, которую в 1983-1985 гг. применяли всего 2,5\% молодых замужних жительниц Саратова, 2\% москвичек и 1,4\% жительниц Уфы, тогда как сейчас каждая пятая горожанка моложе 35 лет, применяющая методы контрацепции, полагается на ОК. Это, конечно, не 2/3, как, например, в Португалии, но тенденция роста популярности ОК очевидна. Увеличился и процент использующих другой высокоэффективный метод - внутриматочную контрацепцию. Но особенно выросла распространенность презерватива: с 15-24\% в середине 1980-х годов до 39\% всех пользователей контрацепции в 2011 г.

Несмотря на несомненные значительные изменения последнего времени, контрацептивная практика россиян все еще существенно отличается от соответствующей практики жителей стран, прошедших контрацептивную революцию 1960-х - 1970-х годов. В России меньше распространены три вида самой эффективной контрацепции: гормональной, внутриматочной и стерилизации. Как видно на рисунке 5 , во многих странах 
три четверти и более пар прибегают к эффективной контрацепции, тогда как в России этот показатель не достигает и половины.

Таблица 7. Структура методов контрацепции, применяемых женщинами моложе 35 лет, проживающими совместно с партнером и имеющими одного или двух детей, \%

\begin{tabular}{l|r|r|r|c}
\hline & \multicolumn{3}{|c|}{$1983-1985$} & 2011 \\
\cline { 2 - 5 } & Москва & Саратов & Уфа & городское население России \\
\hline Применяют методы контрацепции & 100 & 100 & 100 & 100 \\
в том числе: & & & & \\
$\quad$ ВМС & 9,8 & 8,5 & 14,5 & 17,2 \\
оральная контрацепция & 2,0 & 2,5 & 1,4 & 20,1 \\
презерватив & 24,4 & 20,5 & 15,1 & 38,8 \\
химические средства (спермициды) & 2,5 & 3,0 & 4,2 & 1,7 \\
женская стерилизация & - & - & - & 0,5 \\
прерванный половой акт & 24,9 & 20,7 & 19,2 & 15,9 \\
календарный метод & 27,0 & 27,6 & 26,0 & 4,3 \\
спринцевание & 8,1 & 17,0 & 18,2 & 0,4 \\
другое & 1,3 & 0,2 & 1,4 & 1,1 \\
\hline
\end{tabular}

Примечание: 1983-1985 г2. - «применяют в настоящее время»; 2011 г. - «применяют в течение 30 дней перед опросом».

Источники: 1983-1985 ге. - [Бабин 1986]; 2011 г. - расчеты авторов на основе базы данных ВОРЗ.

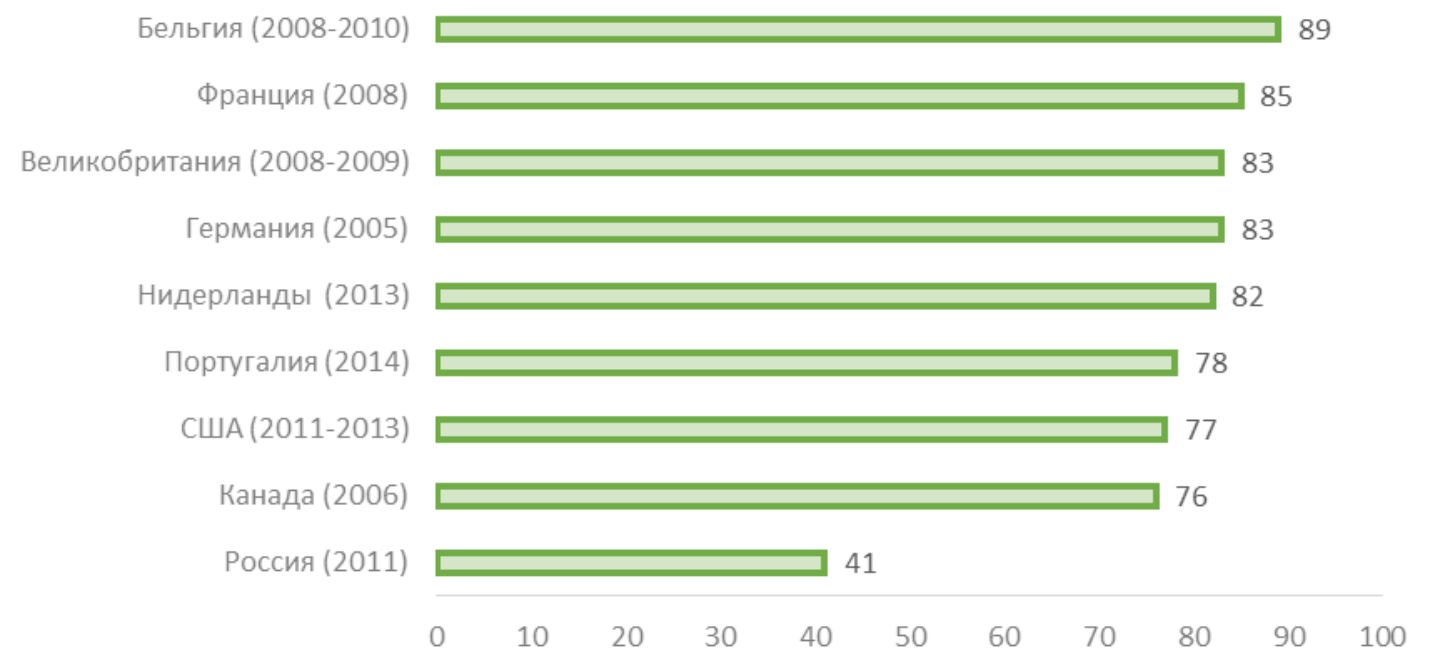

Рисунок 5. Доля женщин, применяющих три вида контрацепции (гормональную*, внутриматочную и стерилизацию), среди всех женщин, состоящих в браке/партнерстве и прибегающих к контрацепции, \%

Примечание: * - Включая таблетки, инъекции, импланты; Бельгия - включая также экстренную контрацепциию.

Источники: [UN 2016]; Россия - расчеты авторов на основе базы данных ВОРЗ.

Структура методов контрацепции в разных странах разная. Например, во Франции, Бельгии, Португалии, Канаде, Чехии свыше 40\% женщин, состоящих в браке или партнерстве (или сексуально активных), используют гормональные таблетки [UN 2016]. В Великобритании около трети всех пар (29\%) прибегают к контрацептивной стерилизации, причем мужская стерилизация более распространена, чем женская; еще примерно столько 
же (31\%) применяют гормональные методы. В США распространенность стерилизации еще выше: 33\% пар [UN 2016]. Но все эти методы достаточно надежны.

О современной структуре контрацепции в России этого сказать нельзя. Хотя она и значительно улучшилась по сравнению с советским периодом, ее трудно назвать оптимальной - в ней очень велика доля относительно ненадежных методов, что сопряжено с риском нежелательного зачатия и последующего аборта. Но положение не остается неизменным, и можно надеяться, что контрацептивная революция в России в недалеком будущем достигнет своего завершения.

\section{ЗАКЛЮЧЕНИЕ}

Во всех обществах, совершивших демографический переход (а в мире их становится все больше и больше), индивидуальное регулирование деторождения - неотъемлемая сторона семейной и сексуальной жизни человека. Все такие общества признают право женщины или супружеской пары свободно решать вопрос о желаемом числе детей и о сроках их появления на свет. XX век принес не только признание этого права, но и удобные, безопасные и эффективные методы его реализации. Их быстрое распространение в 1960-е - 1970-е годы во многих странах и составило содержание контрацептивной революции. Новые, более совершенные методы контрацепции оттеснили на обочину такой архаичный способ регулирования деторождения, как аборт, и свели его использование к минимуму. Одновременно они открыли перед женщинами и мужчинами небывалые возможности уверенно планировать свою жизнь так, чтобы рождение и воспитание детей наиболее удобным для родителей образом сочеталось с решением других жизненно важных для них задач - получением образования, достижением определенного социального статуса, необходимого уровня материального благополучия. Эта исторически новая ситуация одинаково выигрышна и для родителей, и для детей, и для всего общества.

К сожалению, на протяжении нескольких десятилетий Россия вместе со всем СССР оставалась в стороне от этого движения, общего для многих стран сходного с ней уровня развития, и практически не принимала участия в контрацептивной революции. Знаменательные перемены начались только в 1990-е годы. Именно тогда Россия стала быстро наверстывать упущенное время, и сейчас можно с определенностью утверждать, что примерно с середины 1990-х годов контрацептивная революция идет и в нашей стране. Едва ли не самое яркое свидетельство этого - быстро сокращающееся число абортов и сближение числа рождений с числом зачатий: люди все более уверенно и умело планируют появление на свет своих детей.

В то же время нельзя не видеть, что контрацептивная революция в России пока не завершена и не все препятствия на ее пути преодолены. И дело не только в том, что структура контрацепции в России все еще несколько архаична, в ней велика доля не самых надежных методов, требующих повседневной бдительности и самодисциплины. О новейших методах долгосрочного действия (например, гормональных имплантах и инъекциях) мало кто знает. Сохраняется воспитанное в советское время подозрительное отношение к гормональной контрацепции. Стерилизация среди россиян непопулярна. 
Важно еще и то, что общество в лице своих государственных институтов недостаточно осознало социальную значимость того сдвига, который получил название «контрацептивной революции», его тесную связь с общими переменами в жизни современного человека.

В российском общественном мнении, в сознании многих российских политиков все еще живет миф о том, что планирование семьи и доступная контрацепция ведут к снижению рождаемости. Между тем этот миф легко опровергается примером многих европейских стран. Так, во Франции, имеющей едва ли не самый высокий в Европе уровень рождаемости, существует частичная компенсация затрат на противозачаточные средства: 65\% стоимости гормональных таблеток (а это самый популярный метод во Франции), имплантов, ВМС, экстренной контрацепции (при наличии рецепта) покрываются базовой страховкой ${ }^{17}$. Несовершеннолетние французские подростки имеют возможность получить контрацептивы бесплатно в специальных центрах планирования семьи или рецепт на бесплатные контрацептивы у школьной медсестры [IPPF EN 2015]. Начиная с 6 лет, для французских школьников предусмотрены обязательные занятия по программе сексуального образования в объеме 2 часа в год.

В Нидерландах профилактика нежелательных беременностей названа одним из приоритетов политики правительства. С 1971 по 2004 г. гормональные средства контрацепции, ВМС, диафрагма, стерилизация полностью покрывались базовой медицинской страховкой, после 2004 г. - только для женщин младше 21 года, для остальных женщин затраты на контрацепцию могут компенсироваться через систему дополнительного страхования. Консультации по планированию семьи доступны в Нидерландах через врачей общей практики, специальные молодежные клиники и государственные центры сексуального здоровья. Сексуальное образование является обязательным и охватывает школьников от 6 до 15 лет [IPPF EN 2015].

В Германии, где показатели абортов одни из самых низких в мире, для девушек моложе 18 лет стоимость контрацептивов полностью покрывается из фондов обязательного медицинского страхования, а для девушек в возрасте 18-19 лет предоставляется скидка. Как и во многих других странах Европы, в Германии существует система обязательного сексуального образования в школах для детей и подростков с 6 до 18 лет [IPPF EN 2015]. Субсидии на приобретение средств контрацепции предоставляются государством и в Испании.

Bсе это - примеры того, как государство идет навстречу запросам времени и потребностям своих граждан, в отличие от российского государства, которое в лучшем случае предоставляет гражданам возможность самим решать свои личные вопросы, кажущиеся недостойными даже упоминания на фоне куда более важных забот великой державы.

Российский Минздрав предложил разделять понятия «профилактика нежелательной беременности» и «профилактика абортов». По сути, это, конечно, одно и то же, но

\footnotetext{
${ }^{17}$ http://www.radiancehumanis.com/conseils-sante/infos-sante/moyens-contraception-remboursements 
чиновники, введя это искусственное разграничение, под первым предлагают понимать использование контрацепции, а под вторым - меры воздействия на женщину, направленные на сохранение нежелательной беременности, если она случилась. Вся активность Минздрава и всякого рода общественных организаций, специализирующихся на антиабортной риторике, сегодня концентрируется вокруг таким образом трактуемой «профилактики абортов».

В той мере, в какой контрацептивная революция в России все же идет, это происходит благодаря резко расширившимся информационным и рыночным возможностям, но без всякого участия государства. Оно ничего не делает для продвижения современных методов планирования семьи при том, что практически нет семьи, которая в той или иной форме не практиковала бы такое планирование. Согласно опросу ЛевадаЦентра, главным источником информации о методах предохранения от нежелательной беременности россиян являются друзья и знакомые, а не специалисты ${ }^{18}$. В официальных документах, включая документы Министерства здравоохранения, слово «контрацепция»не упоминается. Средства контрацепции не входят в систему обязательного медицинского страхования. Современная контрацепция в России не производится (за редким исключением некоторых ВМС и презервативов) и не разрабатывается, в основном импортируется с Запада (хотя производится, наверно, как и многое другое, в Азии). Сексуальное образование в России отсутствует.

Тем не менее контрацептивная революция в России идет довольно высокими темпами, равнодушие государства не способствует ее ускорению, но и не может ее остановить.

\section{ЛИТЕРАТУРА}

Авдеев А.А. (1989). Аборты и рождаемость // Социологические исследования. 3: 54-63.

Бабин Е.Б. (1986). Контрацептивное поведение супругов в городских семьях // Детность семьи: вчера, сегодня, завтра. М.: Мысль: 146-156.

Белова В.А., Л.Е. Дарский (1972). Статистика мнений в изучении рождаемости. М.: Статистика. 143 с.

BО3 Европейское бюро. Европейское семейство баз данных «Здоровье для всех». URL: http://www.euro.who.int/ru/data-and-evidence/databases/european-health-for-all-family-ofdatabases-hfa-db (дата обращения: 23.03.2017)

Генс А. Б. (1926). Аборт в РСФСР. Доклад на Всесоюзном съезде по охране материнства и младенчества (Москва, 1-7 декабря 1925 г.). М.: «Охрана материнства и младенчества». 26 с.

Генс А.Б. (1929). Проблема аборта в СССР. М.: Госмедиздат. 91 с.

${ }^{18}$ Кочергина Е. (2017). Репродукция и аборты. Левада-Центр. Пресс-релиз. 20 марта. URL: http://www.levada.ru/2017/03/20/reproduktsiya-i-aborty/ (дата обращения: 23.03.2017). 
Демографическая модернизация России: 1900-2000 (2006) / Под ред. А.Г.Вишневского. М.: Новое издательство. 608 с.

Кон И.С. (2010). Клубничка на березке: Сексуальная культура в России. М.: Время. 608 с.

Методы предупреждения беременности (1983).. Методические рекомендации. М.:

Министерство здравоохранения СССР, Главное Управление лечебнопрофилактической помощи детям и матерям. 26 с.

Окинчиц Л.Л. (1912). Как бороться с преступным выкидышем // Труды IV съезда Общества российских акушеров и гинекологов. СПб.: 53-66.

ООН (1994). Доклад Международной конференции по народонаселению и развитию. Каир, 5-13 сентября 1994 г.

Паевский В.В. (1970). К вопросу о рождаемости в Ленинграде (по материалам статистики абортов) // Вопросы демографической и медицинской статистики (Избранные произведения) / Под ред. А.М. Меркова. М.: Статистика: 308-341.

Полчанова С.Л. (1973). Анализ методических ошибок противоабортной пропаганды // Труды Центрального научно-исследовательского института санитарного просвещения. IV. М.: Министерство здравоохранения ССCР: 36-41.

Садвокасова Е.А. (1969). Социально-гигиенические аспекты регулирования размеров семьи. М.: Медицина: 192.

Сакевич В.И. (2009). Особенности внутрисемейного контроля рождаемости в России // Родители и дети, мужчины и женщины в семье и обществе. Сборник аналитических статей. Выпуск 2 / Под науч. ред. С.В. Захарова, Т.М. Малевой, О.В. Синявской. М.: НИСП: 119-138.

Сакевич В.И. (2010). Планирование семьи в России // Демоскоп Weekly, 409-410. URL: http://demoscope.ru/weekly/2010/0409/tema01.php (дата обращения: 15.03.2017)

Сови А. (1977). Общая теория населения. Том второй. Жизнь населений. М.: Прогресс. $520 \mathrm{c}$.

Тёмкина А. (2011). Контрацептивные практики российских женщин: (без)опасность и медикализация // Здоровье и интимная жизнь: социологические подходы. Сборник статей / Под ред. Е. Здравомысловой и А. Тёмкиной. СПб.: Издательство ЕУСПб. С. 210-239.

Тёмкина А. (2013). Советы гинекологов о контрацепции и планировании беременности в контексте современной биополитики в России // Журнал исследований социальной политики. 11 (1): 7-24.

Троицкая И.А., Г. Андерссон (2011). Переход к современной контрацепции в России: результаты обследований «Репродуктивное здоровье женщин» 1996 и 1999 гг. // Рождаемость и планирование семьи в России: история и перспективы: Сборник статей / под ред. И.А. Троицкой, А.А. Авдеева. М.: ТЕИС: 61-86.

Шарапова О.В., Н.Г. Баклаенко (2003). Медико-социальные и правовые аспекты абортов в Российской Федерации // Планирование семьи. 3: 2-7.

Chesnais J.-C. (1986). La transition démographique. Etapes, formes, implications économiques. Etude de séries temporelles (1720-1984) relatives à 67 pays / Institut national d'études démographiques. Travaux et documents. Cahier no 113. Presses universitaires de France. $580 \mathrm{p}$. 
Cleland J. (2009). Contraception in historical and global perspective // Best practice and research clinical obstetrics and gynaecology. 23: 165-176.

Davey C. (1988). Birth control in Britain during the interwar years: evidence from the stopes correspondence // Journal of family history. 13 (1): 329-345.

David H.P., A.A. Popov (1999). Russian Federation and USSR Successor States // From abortion to contraception: a resource to public policies and reproductive behavior in Central and Eastern Europe from 1917 to the present / H.P. David, ed. with the assistance of J. Skilogianis. Westport, CT/London: Greenwood Press. 382 p.

Festy P. (1979). La fécondité des pays occidentaux de 1870 à 1970. / Institut national d'études démographiques. Travaux et documents. Cahier $\mathrm{n}^{0}$ 85. Presses universitaires de France. $392 \mathrm{p}$.

Frejka T. (2008). Overview chapter 3: birth regulation in Europe: completing the contraceptive revolution // Demographic research. 19 (5): 73-84.

Frejka T., J.A. Ross (2001) Paths to subreplacement fertility: the empirical evidence // Population and development review. 27. Supplement: global fertility transition: 213-254.

IPPF EN (2015). Barometer of Women's access to modern contraceptive choice in $16 \mathrm{EU}$ countries. URL: http://www.ippfen.org/resource/barometer-womens-access-moderncontraceptive-choice-16-eu-countries-call-action (дата обращения: 23.03.2017)

Leridon H. (1981) Fertility and contraception in 12 developed countries // International family planning perspectives. 7 (2): 70-78.

Leridon H., Y. Charbit, P. Collomb, J.-P. Sardon, L. Toulemon (1987). La seconde révolution contraceptive. La régulation des naissances en France de 1950 à 1985 // Travaux et document. Cahier $\mathrm{n}^{0}$ 117. Paris: INED. $380 \mathrm{p}$.

Lesthaeghe R. (2010). The unfolding story of the second demographic transition // Population and development review. 36 (2): 211-251.

Potts M., P. Selman (1979). Society and fertility. Plymouth: Macdonald and Evans Ltd. 374 p.

UN (2016). UN, Department of Economic and Social Affairs, Population Division. World Contraceptive Use 2016 (POP/DB/CP/Rev2016).

Westoff Ch.F. (1972). The Modernization of U.S. Contraceptive Practice // Family planning perspectives. 4 (3): 9-12.

Westoff Ch.F. (1975). The yield of the imperfect: The 1970 National fertility study // Demography. 12 (4): 573-580.

Westoff Ch.F., N.B. Ryder (1977). The contraceptive revolution. Princeton University Press. $388 \mathrm{p}$.

Wrigley E.A. (1969). Population and history. N.Y.: McGraw-Hill. 256 p. 


\title{
CONTRACEPTIVE REVOLUTION IN RUSSIA
}

\author{
ANATOLY VISHVEVSKY, BORIS DENISOV, VICTORIA SAKEVICH
}

\begin{abstract}
In the 1960s and 1970s, with the introduction of hormonal contraception, as well as of a new generation of intrauterine contraception, Western countries saw cardinal changes in methods of fertility regulation so significant that the American demographers Westoff and Ryder called them "The contraceptive revolution." By this time, the transition to low fertility in developed countries, as, indeed, in Russia, was completed, and family planning had become a common practice. However, the new technologies significantly increased the effectiveness of birth control, and this change would have important social and demographic consequences.Underestimation of the importance of family planning and underdevelopment of the corresponding services in the USSR and in Russia led to the contraceptive revolution beginning here much later than in the West, already in the post-Soviet years with the arrival of a market economy and information openness. For decades, induced abortion played a key role in the regulation offertility, and only in the 1990s did modern methods of contraception become widespread and the unfavorable ratio of abortions to births begin to change for the better. The article describes the composition of contraceptive methods used in the countries of European culture and in Russia, and attempts to explain the difference in this composition. Based on national representative sampling survey data, an analysis is made of current practice of contraceptive use in Russia. The conclusion is drawn that the contraceptive revolution in Russia is proceeding rather quickly, although is not receiving substantial state support.
\end{abstract}

Keywords: birth control, family planning, contraception, contraceptive revolution, abortions, fertility.

ANATOly G. ViShVEVSKy (avishnevsky@hse.ru), NATIONAL RESEARCH UNIVERSITY Higher SCHOOL OF ECONOMICS, RUSSIA.

Boris P. Denisov (denisov@demography.ru), Lomonosov Moscow State University, Russia.

Victoria I. SAKEVICH (vsakevich@hse.ru), NATIONAL RESEARCH UNIVERSITY HigHER SCHOOL OF ECONOMICS, RUSSIA.

THE RESULTS OF THE PROJECT "DEMOGRAPHIC DEVELOPMENT IN RUSSIA IN 2005-2015 IN THE CONTEXT OF LONG-TERM TRENDS", CARRIED OUT WITHIN THE FRAMEWORK OF THE BASIC RESEARCH PROGRAM AT THE NATIONAL RESEARCH UNIVERSITY HIGHER SCHOOL OF ECONOMICS (HSE) IN 2016, ARE PRESENTED IN THIS PAPER.

DATE RECEIVED: NOVEMBER 2016.

\section{REFERENCES}

Avdeev A.A. (1989). Aborty i rozhdaemost' [Abortions and fertility] // Sotsiologicheskie issledovaniya [Sociological Studies]. 3: 54-63.

Babin E.B. (1986). Kontratseptivnoe povedenie suprugov v gorodskikh sem'yakh [Spousal contraceptive behavior of urban families] // Detnost' sem'i: vchera, segodnya, zavtra [Family's fertility: yesterday, today, tomorrow]. Moscow: Mysl': 146-156.

Belova V.A., L.E. Darsky (1972). Statistika mneniy v izuchenii rozhdaemosti [Statistics of attitudes in the study of fertility]. Moscow: Statistika. 143 p.

Chesnais J.-C. (1986). La transition démographique. Etapes, formes, implications économiques. Etude de séries temporelles (1720-1984) relatives à 67 pays / Institut national d'études démographiques. Travaux et documents. Cahier no 113. Presses universitaires de France. $580 \mathrm{p}$.

Cleland J. (2009). Contraception in historical and global perspective // Best practice and research clinical obstetrics and gynaecology. 23: 165-176. 
Davey C. (1988). Birth control in Britain during the interwar years: evidence from the stopes correspondence // Journal of family history. 13 (1): 329-345.

David H.P., A.A. Popov (1999). Russian Federation and USSR Successor States // From abortion to contraception: a resource to public policies and reproductive behavior in Central and Eastern Europe from 1917 to the present / H.P. David, ed. with the assistance of J. Skilogianis. Westport, CT/London: Greenwood Press. 382 p.

Demograficheskaya modernizatsiya Rossii: 1900-2000 [Demographic modernization of Russia: 1900-2000] (2006) / A.G. Vishnevsky, ed. Moscow: Novoe izdatel'stvo. 608 p.

Festy P. (1979). La fécondité des pays occidentaux de 1870 à 1970 / Institut national d'études démographiques. Travaux et documents. Cahier $n^{0} 85$. Presses universitaires de France. $392 \mathrm{p}$.

Frejka T. (2008). Overview chapter 3: birth regulation in Europe: completing the contraceptive revolution // Demographic research. 19 (5): 73-84.

Frejka T., J.A. Ross (2001) Paths to subreplacement fertility: the empirical evidence // Population and development review. 27. Supplement: global fertility transition: 213-254.

Gens A.B. (1926). Abort v RSFSR [Abortion in RSFSR]. Doklad na Vsesoyuznom s"ezde po okhrane materinstva i mladenchestva (Moskva, 1-7 dekabrya 1925 g.) [All Union congress on motherhood and infancy care (Moscow, 1-7 December 1925]. Moscow: Okhrana materinstva i mladenchestva. $26 \mathrm{p}$.

Gens A.B. (1929). Problema aborta v SSSR [Abortion problem in the USSR]. Moscow: Gosmedizdat. $91 \mathrm{p}$.

IPPF EN (2015). Barometer of women's access to modern contraceptive choice in $16 \mathrm{EU}$ countries. URL: http://www.ippfen.org/resource/barometer-womens-access-moderncontraceptive-choice-16-eu-countries-call-action (accessed: 23.01.2017)

Kon I.S. (2010). Klubnichka na berezke: Seksual'naya kul'tura v Rossii [Strawberry on a birch tree. Russian sexual culture]. Moscow: Vremya. 608 p.

Leridon H. (1981) Fertility and contraception in 12 developed countries // International family planning perspectives. 7 (2): 70-78.

Leridon H., Y. Charbit, P. Collomb, J.-P. Sardon, L. Toulemon (1987). La seconde révolution contraceptive. La régulation des naissances en France de 1950 à 1985 // Travaux et document. Cahier $\mathrm{n}^{0}$ 117. Paris: INED. $380 \mathrm{p}$.

Lesthaeghe R. (2010). The unfolding story of the second demographic transition // Population and development review. 36 (2): 211-251.

Metody preduprezhdeniya beremennosti [Methods of pregnancy prevention] (1983).

Metodicheskie rekomendatsii [Recommendations]. Moscow: Ministerstvo zdravookhraneniya SSSR, Glavnoe Upravlenie lechebno-profilakticheskoy pomoshchi detyam i materyam. $26 \mathrm{p}$.

Okinchits L.L. (1912). Kak borot'sya s prestupnym vykidyshem [How to fight against criminal abortion] // Trudy IV s"ezda Obshchestva rossiyskikh akusherov i ginekologov [Proceedings of the Fourth Congress of the Society of Russian obstetricians and gynecologists]. SanktPeterburg: 53-66.

Paevsky V.V. (1970). K voprosu o rozhdaemosti v Leningrade (po materialam statistiki abortov) [On the question of fertility in Leningrad (based on abortion statistics)] // Voprosy demograficheskoy i meditsinskoy statistiki (Izbrannye proizvedeniya) [Issues of 
demographic and medical statistics. Selected works] / A.M. Merkov, ed. Moscow: Statistika: 308-341.

Polchanova S.L. (1973). Analiz metodicheskikh oshibok protivoabortnoy propagandy [Analysis of methodological errors of anti-abortion propaganda] // Trudy Tsentral'nogo nauchnoissledovatel'skogo instituta sanitarnogo prosveshcheniya [Proceedings of the Central scientific research institute of health education]. IV. Moscow: Ministerstvo zdravookhraneniya SSSR: $36-41$.

Potts M., P. Selman (1979). Society and fertility. Plymouth: Macdonald and Evans Ltd. 374 p.

Sadvokasova E.A. (1969). Sotsial'no-gigienicheskie aspekty regulirovaniya razmerov sem'i [Socio-hygienic aspects of family size regulation]. Moscow: Meditsina. $192 \mathrm{p}$.

Sakevich V.I. (2009). Osobennosti vnutrisemeynogo kontrolya rozhdaemosti v Rossii

[Characteristics of birth control in Russia] // Roditeli i deti, muzhchiny i zhenshchiny v sem'e i obshchestve. Sbornik analiticheskikh statey [Parents and children, men and women in family and society. Collection of analytical articles] / S.V. Zakharov, T.M. Maleva, O.V. Sinyavskaya, eds. Issue 2. Moscow: NISP: 119-138.

Sakevich V.I. (2010). Planirovanie sem'i v Rossii [Family planning in Russia] // Demoscope Weekly: 409-410. URL: http://demoscope.ru/weekly/2010/0409/tema01.php (accessed: 15.01.2017).

Sauvy A. (1977). Obshchaya teoriya naseleniya. Tom 2. Zhizn' naseleniy [General theory of population. Vol. 2. The life of populations]. Moscow: Progress. 520 p.

Sharapova O.V., N.G. Baklaenko (2003). Mediko-sotsial'nye i pravovye aspekty abortov v Rossiyskoy Federatsii [Medico-social and legal aspects of abortions in the Russian Federation] // Planirovanie sem'i [Family planning]. 3: 2-7.

Temkina A. (2011). Kontratseptivnye praktiki rossiyskikh zhenshchin: (bez)opasnost' i medikalizatsiya [Contraceptive practices of Russian women: (in)security and medication] // Zdorov'e i intimnaya zhizn': sotsiologicheskie podkhody. Sbornik statey [Health and intimate life: sociological approaches. Collection of articles] / E. Zdravomyslova, A. Temkina, eds. Sankt-Peterburg: Izdatel'stvo EUSPb: 210-239.

Temkina A. (2013). Sovety ginekologov o kontratseptsii i planirovanii beremennosti v kontekste sovremennoy biopolitiki v Rossii [Gynecologists' advices on contraception and pregnancy planning in the context of modern biopolitics in Russia] // Zhurnal issledovaniy sotsial'noy politiki [The journal of social policy studies]. 11 (1): 7-24.

Troitskaya I.A., G. Andersson (2011). Perekhod k sovremennoy kontratseptsii v Rossii: rezul'taty obsledovaniy «Reproduktivnoe zdorov'e zhenshchin» 1996 i 1999 gg. [Transition to modern contraception in Russia: evidence from the 1996 and 1999 women's reproductive health surveys] // Rozhdaemost' i planirovanie sem'i v Rossii: istoriya i perspektivy: Sbornik statey [Fertility and family planning in Russia: history and perspectives. Collection of articles] / I.A. Troitskaia, A.A. Avdeev, eds. Moscow: TEIS: 61-86.

UN (1994). Report of the International Conference on population and development, Cairo, 5-13 September 1994.

UN (2016). UN, Department of Economic and Social Affairs, Population Division. World Contraceptive Use 2016 (POP/DB/CP/Rev2016).

Westoff Ch.F. (1972). The Modernization of U.S. Contraceptive practice // Family planning perspectives. 4 (3): 9-12. 
Westoff Ch.F. (1975). The yield of the imperfect: The 1970 National fertility study // Demography. 12 (4): 573-580.

Westoff Ch.F., N.B. Ryder (1977). The contraceptive revolution. Princeton University Press. $388 \mathrm{p}$.

WHO Regional Office for Europe. European health for all family of databases. URL: http://www.euro.who.int/en/data-and-evidence/databases/european-health-for-all-family-ofdatabases-hfa-db (accessed: 23.03.2017).

Wrigley E.A. (1969). Population and history. N.Y.: McGraw-Hill. 256 p. 